\title{
Virus-like Particles Associated with the Mycoplasmas of Clover Phyllody in the Plant and in the Insect Vector
}

\author{
By J. P. GOURRET, P. L. MAILLET AND J. GOURANTON \\ Laboratoire de Biologie Cellulaire, \\ Université de Rennes-Beaulieu-35, France
}

(Received I2 May 1972)

\begin{abstract}
S UMMAR Y
In a few phloem cells in root nodules of clover (Trifolium repens L.) and salivary glands of Euscelis lineolatus Brullé, which were naturally or experimentally infected by the mycoplasmas of clover phyllody, rod-shaped virus-like particles were found which had at least one rounded end. These particles had a diameter of $27 \pm 3 \mathrm{~nm}$, a dense core of diameter $16 \pm 2 \mathrm{~nm}$ and a clear axis. Their mean length was between 50 and $90 \mathrm{~nm}$. Even when they were free in the phloem sap of the plant or in the haemolymph of the insect they were in the vicinity of some mycoplasmas. Sometimes they were crowded in a monolayer inside the cytoplasm of the plant cell. They were also found in the form of a rosette around some mycoplasmas which seemed degenerated. The occurrence, size, shape, internal structure and position of these virus-like particles is illustrated; their nature and pathogenicity in comparison with Mycoplasmatales Virus laidlawii I and the virus-like particles sometimes associated with plant pathogenic mycoplasmas is discussed.
\end{abstract}

\section{INTRODUCTION}

Viruses are known in almost every group of living organisms, both Eucaryotes (Vertebrates, Invertebrates, Plants) and Procaryotes (Bacteria, Cyanophyceae). Mycoplasmas may also be infected by viruses, since Gourlay (1970) isolated an agent which multiplies in cultures of Mycoplasma (Acholeplasma) laidlawii I.

Mycoplasmas, which are known to occur in about fifty plant diseases (Davis \& Whitcomb, I97I), parasitize the phloem (Gourret, I970). They develop in this tissue and may contaminate the whole plant. Part of their life-cycle proceeds in an insect-vector, generally a leafhopper (suborder Homoptera, series Auchenorhyncha) in which the progression of infection and the sites of multiplication have been studied (Maillet, 1970; Maillet \& Gouranton, 1970; Maillet \& Gouranton, 1971).

During our study on clover phyllody, we sometimes observed virus-like particles in the phloem of the clover root nodules and in salivary glands of the insect vector. These particles seemed to be associated with mycoplasmas, and this is illustrated and discussed in this paper.

\section{METHODS}

Root nodules were taken from a clover (Trifolium repens L.) showing a natural phyllody/ hypertrophy of the calyx for some inflorescences or transformation of the carpels into trifoliate leaves for the others. Salivary glands of the insects (Euscelis lineolatus Brullé) which had been feeding for 44 days on the diseased plants were dissected. The same was done with healthy clover and insects fed on healthy plants. 

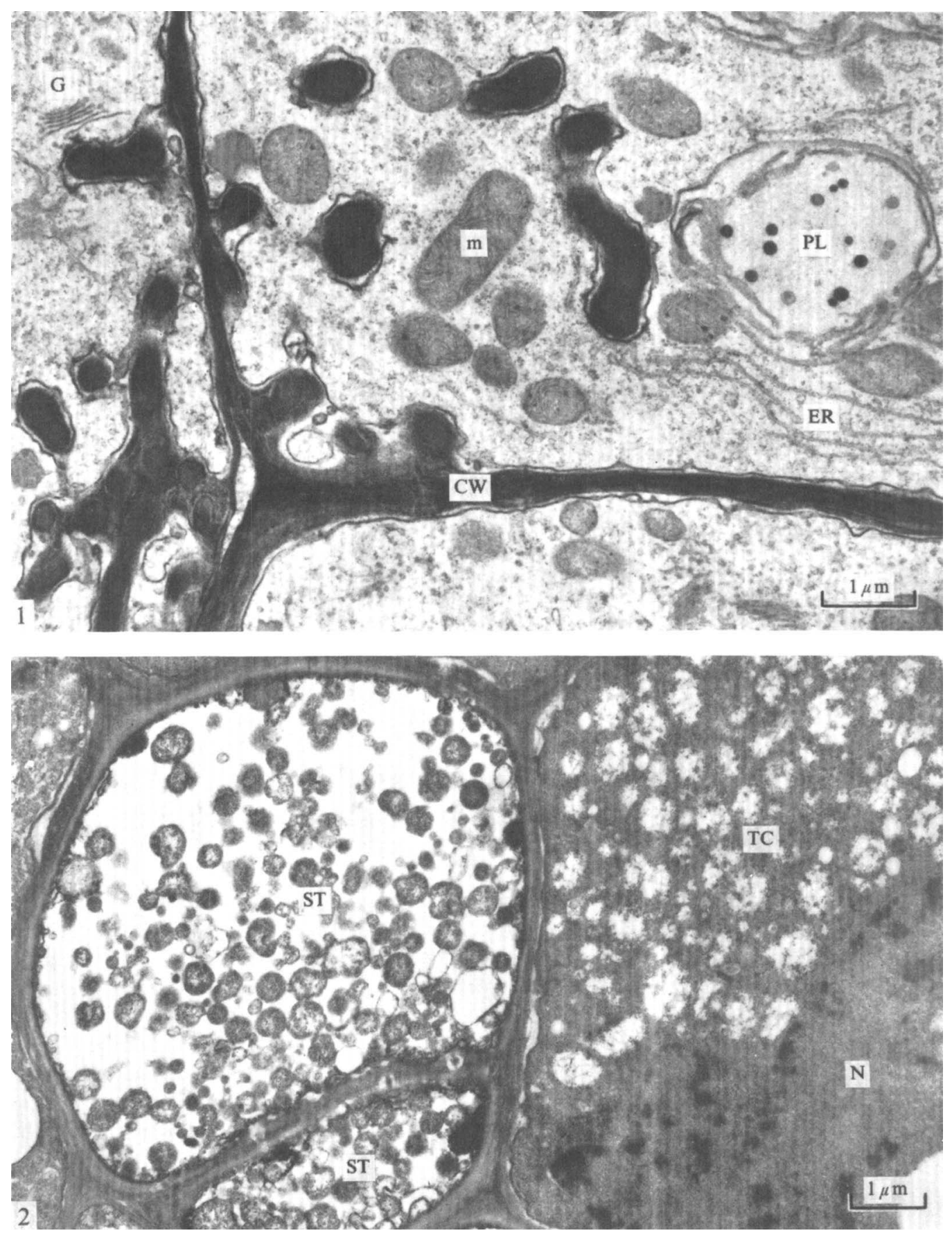

\section{EXPLANATION OF FIGURES}

Abbreviations: bl, basal lamina; CW, cell wall; ER, endoplasmic reticulum; G, dictyosome; m, mitochondrion; mf, muscular fibre; M, mycoplasma; N, nucleus; PL, plastid; S, saliva; ST, sieve tube; TC, transfer cell; VP, virus-like particles.

Fig. I, 2. Plant cells and mycoplasmas

Fig. 1. Part of healthy pericyclic cells showing wall ingrowths (transfer cell).

Fig. 2. Sieve tubes and their contiguous pericyclic cells both infected by mycoplasmas. No viruslike particle is visible. 
Plant and insect samples were prefixed at $4{ }^{\circ} \mathrm{C}$ in glutaraldehyde $(2.5 \%, \mathrm{v} / \mathrm{v})$ in $0.1 \mathrm{M}$ cacodylate buffer, $\mathrm{pH} 7 \cdot 2$, for $90 \mathrm{~min}$, and then postfixed in osmium tetroxide $(2 \%, \mathrm{w} / \mathrm{v})$ in the same buffer for $\mathrm{I} h$. After dehydration, the samples were embedded in Epon. Ultrathin sections were stained with uranyl acetate and lead citrate.

\section{RESULTS}

\section{Plant cells and mycoplasmas}

The vascular bundle. The vascular system of the root nodules consists of several vascular bundles around the parenchyma where the symbiotic Rhizobia multiply. Each bundle is limited by an endodermis and contains generally two layers of pericyclic cells, xylem and phloem cells. The vascular bundles differentiate from the apical meristem of the nodule and are connected to the root which bears this nodule. A striking feature in this differentiation is the formation and then the resorption of wall ingrowths in the pericyclic cells (transfer cells) (Gunning \& Pate, 1969). However, these cells did not contain anything which could be interpreted as an unusual component of a plant cell (Fig. I).

Mycoplasmas. In some sieve tubes of clover showing the phyllody symptoms, many mycoplasmas were present (Fig. 2). Generally they were ovoid or round. Their sizes were variable (from 70 to $800 \mathrm{~nm}$ in diam.). Among the smallest forms, many were very dense and individual ribosomes could be seen. Some large pericyclic cells associated with the phloem and some parenchyma cells were also infected. In the former many large mycoplasmas occupied a large part of the cell cytoplasm.

\section{Salivary glands and mycoplasmas}

Salivary glands. The cells were large and had an endomitotic nucleus. Their cytoplasm was characterized by a great development of endoplasmic reticulum, the numerous secretory granules and a system of cavities where the saliva is formed (Fig. 3). The cytoplasm of these cells contained some microtubules $(25 \mathrm{~nm}$ diam.). The gland was surrounded by a continuous basal lamina and some striated muscle cells, and was connected to nervous fibres where many neurotubules could be seen.

Mycoplasmas. These were most often situated in 'pockets' (Maillet, 1970) between the cytoplasmic membrane and the basal lamina (Fig. 5). Sometimes they were located in the salivary cells where they were either free in the cytoplasm or surrounded by a membrane in a vacuole. They were also encountered in the intracellular salivary canaliculus (Fig. 4).

\section{Virus-like particles}

Virus-like particles in plant cells. In four instances, among the many vascular bundles infected with mycoplasmas we observed tiny rod-shaped particles with at least one rounded end. They were 50 to $90 \mathrm{~nm}$ in length and $27 \pm 3 \mathrm{~nm}$ in diam. (i.e. about three times the thickness of a unit membrane). They had a clear axis surrounded by a dense layer $(16 \pm 2 \mathrm{~nm}$ diam.) and were limited by another electron-dense layer which was much thinner (Fig. 9 to II). These particles were sometimes free in the phloem sap (Fig. 7), or adsorbed to the mycoplasmas, or randomly dispersed at the periphery of the sieve tubes. In the pericyclic cells the particles were sometimes arranged side by side in only one layer, so that they were seen in profile or in cross-section (Fig. 12). Sometimes the particles formed a ring around degenerating dense mycoplasmas from which they seemed to have budded (Fig. 8).

Virus-like particles in salivary cells. In some instances, among the infected salivary glands, the 'pockets' contained particles looking like those seen in the plant (Fig. 13 to 21). Some 

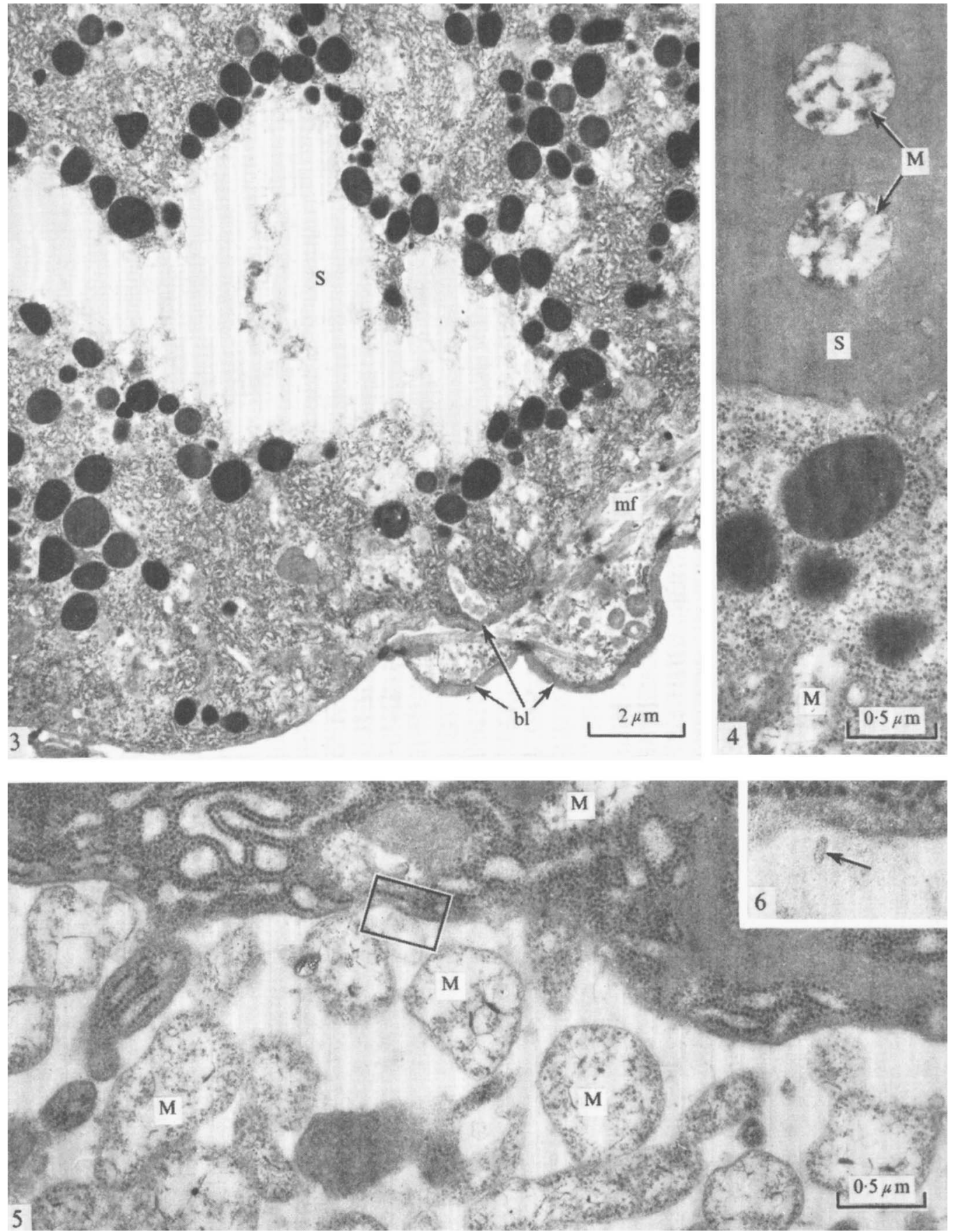

Fig. 3 to 6 . Salivary cells and mycoplasmas.

Fig. 3. Part of a healthy salivary cell.

Fig. 4. Mycoplasmas in the cytoplasm and in a salivary canaliculus.

Fig. 5. Mycoplasmas in a 'pocket' between the basal lamina and the cytoplasmic membrane of a salivary cell.

Fig. 6. The virus-like particle from the insert in Fig. 5. 

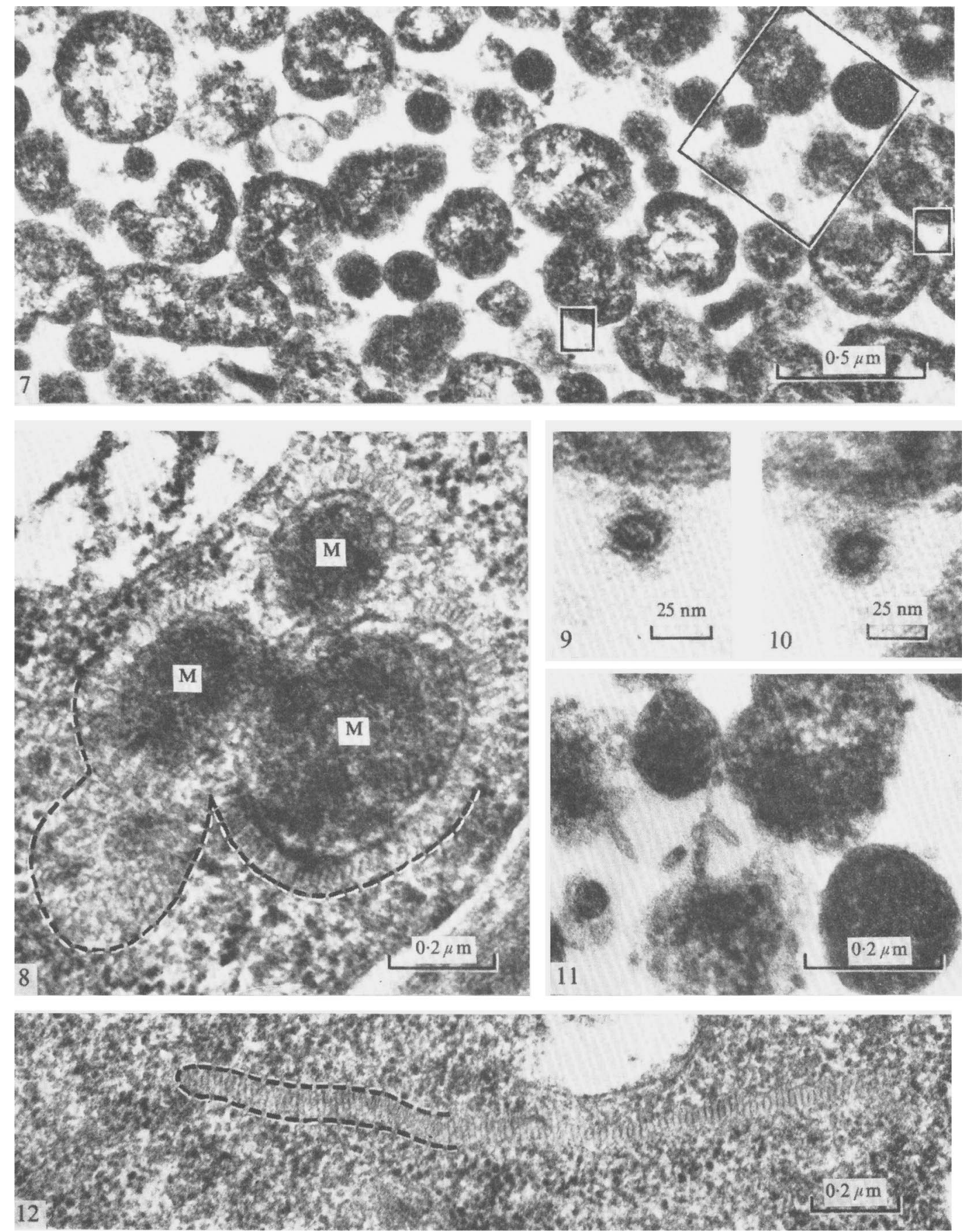

Fig. 7 to I2. Virus-like particles in plant cells

Fig. 7. Mycoplasmas and virus-like particles in the phloem sap of a sieve tube.

Fig. 8. Virus-like particles forming rosettes around degenerating plasmas.

Fig. 9 to II. Inserts from Fig. 7 .

Fig. I2. Virus-like particles forming a monolayer arrangement in the cytoplasm of a pericyclic cell infected with mycoplasmas. 

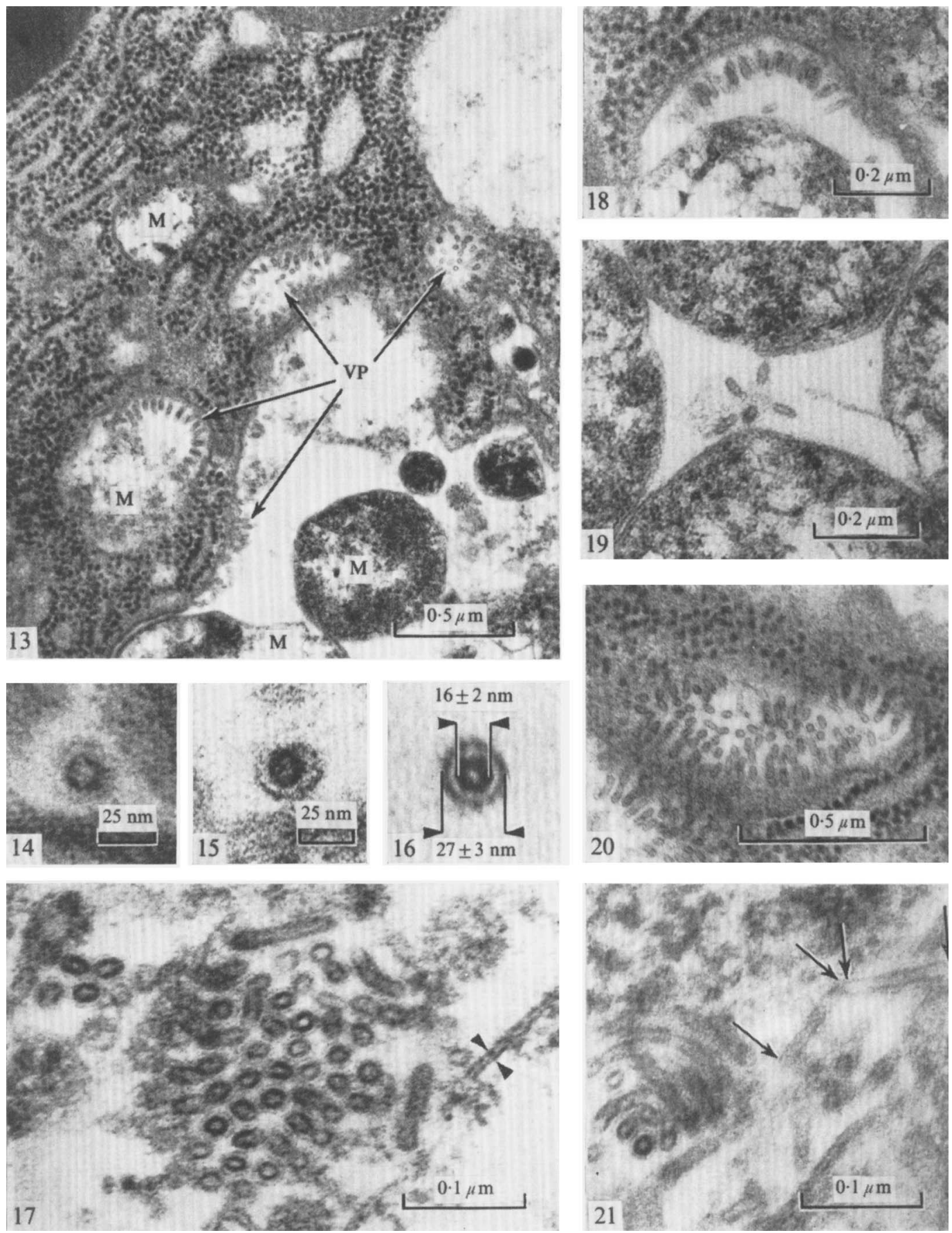

Fig. 13 to $2 \mathrm{I}$. Virus-like particles in salivary cells.

Fig. 13. Virus-like particles associated with mycoplasmas at the basal pole of a salivary cell. Some mycoplasmas are degenerating.

Fig. 14 to I6. Cross-sections of three different virus-like particles.

Fig. 17. Crowded virus-like particles. See between the two arrows the thickness of a unit membrane.

Fig. 18. One mycoplasma and particles in a vacuole of the salivary gland.

Fig. 19. Particles between mycoplasmas.

Fig. 20. Compare the diameter of the ribosomes with the diameter of the dense core of the particles.

Fig. 2I. Longitudinal and cross-sections of virus-like particles. 
Table I. Dimensions of Mycoplasmatales, viruses and virus-like particles associated with plant pathogenic mycoplasmas

\begin{tabular}{|c|c|c|c|}
\hline Authors & Material & Diameter (nm) & Length (nm) \\
\hline $\begin{array}{l}\text { Gourlay, Bruce \& } \\
\text { Garwes (197I) }\end{array}$ & $\begin{array}{c}\text { Mycoplasma } \\
\text { laidlawii } \mathbf{I}\end{array}$ & $14 \cdot 6 \pm 1 \cdot 9$ & $\begin{array}{l}89 \cdot 9 \pm 10 \cdot 0 \\
\text { a few particles up to } 400\end{array}$ \\
\hline Ploaie (1971) & $\begin{array}{l}\text { Clover } \\
\text { dwarf }\end{array}$ & $\begin{array}{l}\text { 3I to } 33 \text { (total diam.) } \\
\text { 2I (central core) } \\
\text { I I (central canal) }\end{array}$ & 85 to 88 \\
\hline $\begin{array}{l}\text { Giannotti, } \\
\text { Devauchelle, } \\
\text { Marchoux \& } \\
\text { Vago (1969) }\end{array}$ & Stolbur SM & $\begin{array}{l}33 \text { (total diam.) } \\
\text { I I (central canal) }\end{array}$ & 200 (maximum) \\
\hline $\begin{array}{l}\text { Marchoux \& } \\
\text { Giannotti (I97I) }\end{array}$ & Stolbur SM & 20 & I60 (approximately) \\
\hline $\begin{array}{l}\text { Gourret, Maillet \& } \\
\text { Gouranton } \\
\text { (this paper) }\end{array}$ & $\begin{array}{l}\text { Clover } \\
\text { phyllody }\end{array}$ & $\begin{array}{l}27 \pm 3 \text { (total diam.) } \\
16 \pm 2 \text { (dense layer diam.) }\end{array}$ & $\begin{array}{l}50 \text { to } 90 \text { (approximately); } \\
\text { a few particles about I } 30 \text { to I } 50\end{array}$ \\
\hline
\end{tabular}

of them were particularly long ( $\mathrm{I} 30$ or even $\mathrm{I} 50 \mathrm{~nm}$. (Fig. 2I). In the salivary cell we also observed virus-like particles forming a ring round the mycoplasmas. When the particles were very numerous, the mycoplasmas seemed to have degenerated in that there was heterogeneity of size and of internal density, and disappearance of ribosomes. Apart from a doubtful instance the particles were never seen inside the mycoplasmas, but always in their vicinity.

\section{DISCUSSION}

The particles we found, in close association with the mycoplasmas of clover phyllody in the root nodules and in the salivary glands of the insect vector, were rod-shaped and had at least one rounded end like the virions isolated from Mycoplasma laidlawii by Gourlay, Bruce \& Garwes (1971), Gourlay (1972), and later studied by Liss \& Maniloff (1971), Maniloff \& Liss (1972) and Milne, Thompson \& Taylor-Robinson (1972). But there was a difference in the sizes (see Table I): MVL I was longer and much thinner than the particles described here. However, MVL I and the central core of the particles had the same diameter, and the outer layer of the particles was a very thin and weak structure, not always preserved in fixed material.

The particles described in this paper were also quite similar in size, shape, internal structure and position to those observed by Ploaie (1971) in the phloem of periwinkles (Vinca rosea) infected with clover dwarf. The question thus arises as to whether clover phyllody and clover dwarf could be the same disease. A comparative study of the botanical symptoms of the diseased plants and the serological characteristics of the agent may prove useful.

Giannotti, Devauchelle, Marchoux \& Vago (1969) and Marchoux \& Giannotti (197I) described particles associated with stolbur SM, a yellows disease of tomato. They did not confirm they were viruses, but considered them rather as a specific product of the pathogen. The particles had dimensions compatible with those given here and some seemed to have budded from mycoplasmas. They were particularly abundant when encountered with degenerated mycoplasmas. 
All these results and our own observations provide original and complementary data to form a logical, though still incomplete, pattern of a viral disease of mycoplasmas.

Concerning the plant diseases clover dwarf, stolbur SM and clover phyllody, it remains to be demonstrated that the particles are (i) true viruses and (ii) infectious for mycoplasmas. The following is relevant:

(i) The regular structure of the particles, their geometrical shape and their tendency to form paracrystalline accumulations are characteristic features of virions. However, their infectivity has to be proved and their nucleic acid component to be studied.

(ii) The plant and insect cells we examined did not contain particles if there were no mycoplasmas; if mycoplasmas were present, particles were encountered in a proportion compatible with a viral type of infection; if particles were very numerous, the mycoplasmas appeared to be altered, suggesting that they had been lysed.

Thus, if the virus-like particles are pathogenic, they are so for the mycoplasmas and not for the plant or insect hosts. The aetiology of the yellows and green petal diseases therefore does not need revision. On the contrary, the particles might be useful in combatting the mycoplasmas. Furthermore, viruses could also provide a good criterion for differentiating and perhaps classifying the mycoplasma agents which have been recognized in the different kinds of plant diseases in the last few years.

Finally, if the hypothesis of viruses infecting plant and animal mycoplasmas is confirmed, the distinctive features of these virions (very different from bacteriophages) would provide a new argument for separating, within the Procaryotes, the Mycoplasmatales from Bacteria and Cyanophyceae.

Note added in proof. Since this manuscript was accepted for publication we learned of a paper by Allen, T. C. (1972), Virology 47, 49I-493. According to this author, bacilliform particles were associated with mycoplasmas within asters infected with a western strain of aster yellows. These particles were comparable with those described in this paper.

We thank Madame M. Mathelier, Mademoiselle G. Boguais and Monsieur B. Morille who have helped us at different stages of this investigation. We also thank Dr D. TaylorRobinson for correcting the English text and for a valuable criticism of the manuscript.

\section{REFERENCES}

DAvis, R. E. \& Whiтcomb, R. F. (I97I). Mycoplasmas, Rickettsiae, and Chlamydiae: possible relation to yellows diseases and other disorders of plants and insects. Annual Review of Phytopathology 9, 1 19-154.

Giannotti, J., Devauchelle, G., Marchoux, G. \& Vago, C. (I969). Recherches sur le pléomorphisme des micro-organismes de type mycoplasme chez les plantes atteintes de jaunisses. Compte rendu hebdomadaire des séances de l'Academie des sciences 268, I354-1 356.

GourLay, R. N. (1970). Isolation of a virus infecting a strain of Mycoplasma laidlawii. Nature, London 225, I 65.

GourLay, R. N. (1972). Ultrastructural studies of Mycoplasmatales viruses. Medical Microbiology and Immunology $\mathbf{1 5 7}, 172$.

Gourlay, R. N., BRUCE, J. \& GARWES, D. J. (I97I). Characterization of Mycoplasmatales Virus laidlawii I. Nature New Biology 229, I I 8-I 19.

GouRRET, J. P. (1970). Ultrastructure et micro-écologie des mycoplasmes de phloème dans trois maladies des pétales verts. Étude des lésions cellulaires. Journal de Microscopie 9, 807-822.

Gunning, B. E. S. \& Pate, J. S. (I969). 'Transfer cells'. Plant cells with wall ingrowths specialized in relation to short distance transport of solutes - Their occurrence, structure, and development. Protoplasma 68, I07-I33.

Liss, A. \& MANILOFF, J. (1971). Isolation of Mycoplasmatales viruses and characterization of MVL I, MVL 52 and MVG 51. Science, New York 173, 725-727. 
MaILlet, P. L. (1970). Contribution à l'étude du cycle des Mycoplasmes, à propos des 'poches à mycoplasmes' dans les glandes salivaires d'Euscelis lineolatus Brullé, vecteur de la Phyllodie du Trèfle. Compte rendu hebdomadaire des séances de l'Academie des sciences 270, 73I-733.

Maillet, P. L. \& Gouranton, J. (1970). L'intestin moyen de certains Homoptères, lieu de transit et de multiplication de particules de type mycoplasme. Compte rendu hebdomadaire des séances de l'Academie des sciences 270, I535-I 537.

Maillet, P. L. \& Gouranton, J. (197I). Étude du cycle biologique du mycoplasme de la phyllodie du trèfle dans l'insecte vecteur, Euscelis lineolatus Brullé (Homoptera, Jassidae). Journal de Microscopie II, I43-I62.

Maniloff, J. \& Liss, A. (1972). Properties of Mycoplasmatales viruses. Medical Microbiology and Immunology $\mathbf{1 5 7}, \mathbf{I 7 2}$.

Marchoux, G. \& Giannotti, J. (I971). Interférences entre deux mycoplasmoses végétales. Physiologie Végétale 9, 595-610.

Milne, R. G., Thompson, G. W. \& TAYLoR-Robinson, D. (1972). Electron microscope observations on Acholeplasma laidlawii viruses. Archiv für die gesamte Virusforschung 37 (in the Press).

PloAie, P. G. (197I). Particles resembling viruses associated with mycoplasma-like organism in plants. Revue Roumaine de Biologie, Botanique 16, 3-6. 